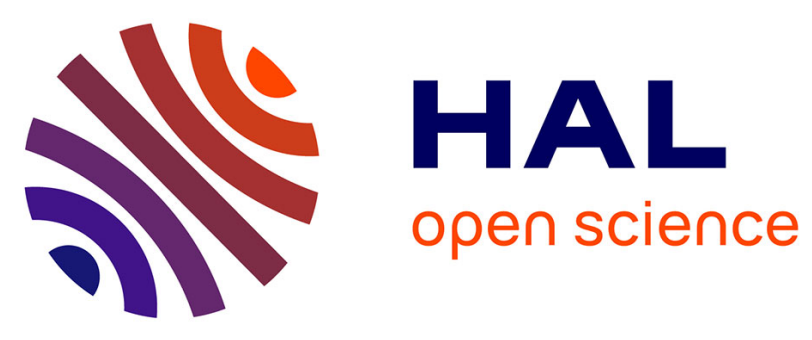

\title{
Truncated thioredoxin (Trx-80) promotes pro-inflammatory macrophages of the M1 phenotype and enhances atherosclerosis
}

Dler Faieeq Darweesh Mahmood, Amna Abderrazak, Dominique Couchie, Oleg Lunov, Vimala Diderot, Tatiana Syrovets, Mohamed-Naceur Slimane, Fabien Gosselet, Thomas Simmet, Mustapha Rouis, et al.

\section{To cite this version:}

Dler Faieeq Darweesh Mahmood, Amna Abderrazak, Dominique Couchie, Oleg Lunov, Vimala Diderot, et al.. Truncated thioredoxin (Trx-80) promotes pro-inflammatory macrophages of the M1 phenotype and enhances atherosclerosis. Journal of Cellular Physiology, 2013, 228 (7), pp.1577-1583. 10.1002/jcp.24319 . hal-01544063

\section{HAL Id: hal-01544063 \\ https://hal.science/hal-01544063}

Submitted on 19 Jul 2021

HAL is a multi-disciplinary open access archive for the deposit and dissemination of scientific research documents, whether they are published or not. The documents may come from teaching and research institutions in France or abroad, or from public or private research centers.
L'archive ouverte pluridisciplinaire HAL, est destinée au dépôt et à la diffusion de documents scientifiques de niveau recherche, publiés ou non, émanant des établissements d'enseignement et de recherche français ou étrangers, des laboratoires publics ou privés. 


\section{Truncated Thioredoxin (Trx-80) Promotes Pro-Inflammatory Macrophages of the M1 Phenotype and Enhances Atherosclerosis}

DLER FAIEEQ DARWEESH MAHMOOD,' AMNA ABDERRAZAK,' DOMINIQUE COUCHIE,' OLEG LUNOV, ${ }^{2}$ VIMALA DIDEROT,' TATIANA SYROVETS, ${ }^{2}$ MOHAMED-NACEUR SLIMANE, ${ }^{3}$ FABIEN GOSSELET, ${ }^{4}$ THOMAS SIMMET, ${ }^{2}$ MUSTAPHA ROUIS, ${ }^{\prime}$ AND KHADIJA EL HADRI ${ }^{*}$

'Unité de Recherche, UR-04, Vieillissement, Stress et Inflammation, Bât. A-6è étage-Case courrier 256,

Université Pierre et Marie Curie, Paris Cedex, France

${ }^{2}$ Institute of Pharmacology of Natural Products and Clinical Pharmacology, Ulm University, Ulm, Germany

${ }^{3}$ Laboratoire de biochimie, Faculté de Médecine de Monastir, Monastir, Tunisia

${ }^{4}$ EA 2465-IFR II 4 IMPRT, Laboratoire de Physiopathologie de la Barrière Hémato-Encéphalique,

Faculté des Sciences Jean Perrin. Université d'Artois, Lens Cedex, France

Vascular cells are particularly susceptible to oxidative stress that is believed to play a key role in the pathogenesis of cardiovascular disorders. Thioredoxin-I (Trx-I) is an oxidative stress-limiting protein with anti-inflammatory and anti-apoptotic properties. In contrast, its truncated form (Trx-80) exerts pro-inflammatory effects. Here we analyzed whether Trx- 80 might exert atherogenic effects by promoting macrophage differentiation into the MI pro-inflammatory phenotype. Trx- $80 \mathrm{at} \mathrm{I} \mathrm{g} / \mathrm{ml}$ significantly attenuated the polarization of anti-inflammatory M2 macrophages induced by exposure to either IL-4 at I5 ng/ml or IL-4/IL- I 3 ( I $0 \mathrm{ng} / \mathrm{ml} \mathrm{each)} \mathrm{in} \mathrm{vitro,} \mathrm{as}$ evidenced by the expression of the characteristic markers, CD206 and IL-I0. By contrast, in LPS-challenged macrophages, Trx-80 significantly potentiated the differentiation into inflammatory MI macrophages as indicated by the expression of the MI cytokines, TNF- $\alpha$ and MCP-I. When Trx-80 was administered to hyperlipoproteinemic ApoE2.Ki mice at $30 \mu \mathrm{g} / \mathrm{g}$ body weight (b.w.) challenged either with LPS at $30 \mu \mathrm{g} / 30 \mathrm{~g}$ (b.w.) or IL-4 at $500 \mathrm{ng} / 30 \mathrm{~g}$ (b.w.), it significantly induced the MI phenotype but inhibited differentiation of M2 macrophages in thymus and liver. When ApoE2.Ki mice were challenged once weekly with LPS for 5 weeks, they showed severe atherosclerotic lesions enriched with macrophages expressing predominantly MI over M2 markers. Such effect was potentiated when mice received daily, in addition to LPS, the Trx-80. Moreover, the Trx- 80 treatment led to a significantly increased aortic lesion area. The ability of Trx-80 to promote differentiation of macrophages into the classical proinflammatory phenotype may explain its atherogenic effects in cardiovascular diseases.

J. Cell. Physiol. 228: I577-I583, 20I3. (C) 2013 Wiley Periodicals, Inc.

Atherosclerosis is a complex inflammatory disease that involves interaction of a variety of cells including monocytes/ macrophages within the vessel wall. A crucial step in this process is the infiltration of monocytes into the subendothelial space of large arteries and their subsequent differentiation into tissue macrophages (Ross, 1999) residing within the atherosclerotic lesions. These macrophages represent a heterogeneous cell population whose activation and function is influenced by various cytokines and microbial products. Thus, interleukin-I $\beta$ (IL-I $\beta$ ), interferon $\gamma($ IFN $\gamma$ ), and lipopolysaccharide (LPS) increase the "classical" or inflammatory activation profile yielding the so-called $\mathrm{MI}$ macrophages (Lumeng et al., 2007), which produce proinflammatory cytokines, such as tumor necrosis factor $\alpha$ (TNF$\alpha$ ), IL-6, and IL- I 2 as well as reactive oxygen species (ROS) and nitrogen intermediates (Gordon, 2003, 2007). Consistently, MI macrophages are associated with inflammation and tissue damage. In contrast, IL-4, IL-I 3 (Stein et al., 1992; Savill et al., 2002; Gordon, 2003), peroxisome proliferator-activated receptor $\gamma$ (PPAR $\gamma$ ) activation (Bouhlel et al., 2007), and adiponectin (Lovren et al., 2010; Ohashi et al., 2010) promote polarization of macrophages into the anti-inflammatory, alternative $M 2$ type. $M 2$ macrophages secrete the antiinflammatory cytokine IL- I0, transforming growth factor $\beta$, IL-
I receptor antagonist, and upregulate mannose receptor (CD206), and arginase- I. Accumulation of M2 macrophages leads to reduction of inflammation. In addition, antiinflammatory macrophages promote angiogenesis, tissue

Conflict of interest: None.

Additional supporting information can be found in the online version of this article.

Contract grant sponsor: The Fondation de France, the Comité Mixte de Cooperation Universitaire (CMCU).

Contract grant sponsor: The German Research Foundation, DFG.

*Correspondence to: Khadija El Hadri, UR-04 Vieillissement, Stress et Inflammation, Université Pierre et Marie Curie-Paris 6, Bât. A. $5^{\text {ème }}$ étage/Case courrier 256, 7, Quai St-Bernard, 75252 Paris Cedex 5, France. E-mail: khadija.zegouagh@upmc.fr

Manuscript Received: 19 August 2012

Manuscript Accepted: 4 January 2013

Accepted manuscript online in Wiley Online Library (wileyonlinelibrary.com): 17 January 2013.

DOI: $10.1002 /$ jcp.24319 
remodeling and repair (Mantovani et al., 200I; Gordon, 2003; Odegaard and Chawla, 2008).

Increasing evidence indicates that risk factors for cardiovascular disease can lead to dramatic increases in the concentration of ROS in the vascular wall. When the rate of ROS formation exceeds the capacity of the antioxidant defense system, oxidative stress occurs, which markedly contributes to arterial inflammation (see review Forstermann, 2008). Thioredoxin-I (Trx-I), a I2-kDa highly conserved protein that has recently been recognized as a critical protective system against oxidative stress (Yamawaki et al., 2003; Forstermann, 2008). Nevertheless, posttranslational modifications of Trx-I have been described. Thus, a C-terminal truncated form, composed of $\mathrm{I}-80$ or $\mathrm{I}-84 \mathrm{~N}$-terminal amino acids (Trx-80), which is either secreted from cells already truncated or cleaved by an unknown enzyme at the cell surface, possesses a cytokinelike activity (Pekkari and Holmgren, 2004). Macrophages have been reported to cleave full-length Trx-I to yield Trx-80 (Bizzarri et al., 2005). Trx-80 is expressed also by U937 monocytes, cytotrophoblasts and CD4 ${ }^{+} \mathrm{T}$ cells (Silberstein et al., 1989; Di Trapani et al., 1998)

The levels of Trx-80 varies from 2 to $175 \mathrm{ng} / \mathrm{ml}$, those of TrxI varies from I 6 to $55 \mathrm{ng} / \mathrm{ml}$ without any correlation to Trx-80, which is highly increased under inflammatory conditions (Pekkari et al., 2000; Cortes-Bratti et al., 20I I). Trx-80 activates monocytes and induces up-regulation of cell surface pathogen recognition receptors, molecules essential for T-cell activation and function (Lemarechal et al., 2007) as well as release of the proinflammatory cytokines evoking inflammation (Bertini et al., 1999).

We have previously shown in vitro that human recombinant Trx-I down-regulates the expression of a number of inflammatory genes such as IL-I $\beta$, TNF- $\alpha$, IL-6, and IL-8 (Billiet et al., 2005). In addition, we have recently shown that intravenous injection of recombinant human Trx-I promotes anti-inflammatory macrophages of the $\mathrm{M} 2$ phenotype and antagonizes atherosclerosis in mice (El Hadri et al., 20I2).

Since Trx 80 has very different properties from the full-length protein, lacking the disulfide reductase activity of the full-length species, and instead having pro-inflammatory cytokine-like effects on immune cells (Pekkari et al., 2000, 200I), we further investigated the vascular proinflammatory mechanism to clarify its atherogenic implication. We found that recombinant human Trx-80 promotes mouse peritoneal and human macrophages toward a "classical" pro-inflammatory MI phenotype. As an in vivo model of atherosclerosis, we have chosen ApoE2.Ki mice expressing human ApoE2 (2/2), which virtually exhibits all characteristics of type III hyperlipoproteinemia in man.

Accordingly, their plasma cholesterol and triglyceride levels are two to three times of that of normolipidemic mice (Sullivan et al., 1998). These animals are markedly defective in clearing $\beta$ migrating VLDL particles, and spontaneously develop atherosclerotic plaques, even on a regular diet. In apoE2.Ki mice on an atherogenic diet (Sullivan et al., 1998) or exposed to LPS, an exacerbation of atherosclerosis is observed (Ostos et al., 2002; Cuaz-Perolin et al., 2008). We demonstrated that Trx-80 treatment led to a significantly increased aortic lesion surface area in ApoE2.Ki mice challenged with LPS.

\section{Methods}

For in vitro studies, both murine peritoneal and human macrophages were used. Cells were left untreated or treated with LPS, IL-4, IL-4/IL-13, Trx-80, or a combination thereof. Recombinant Trx- 80 containing by the LAL method less than $<$ I.0 EU of endotoxin per I $\mu \mathrm{g}$ of protein was obtained from $R \& D$ systems. To exclude any potential endotoxin interference, we have added in all in vitro experiments (except when LPS was added) polymyxin B that is known to neutralize endotoxin. In some samples, a specific antibody against truncated human Trx80 was added. To study the binding of Trx-80, recombinant Trx-80 was fluorescently labeled and incubated with macrophages, and fluorescence images were taken using Zeiss LSM7I 0 confocal scanning microscope. The expression of macrophage phenotype markers, CD206, MCP-I, IL-I0, and TNF- $\alpha$, and other involved genes, activator protein (AP)-I and Ref-I, were investigated at both transcription and protein levels using real-time polymerase chain reaction and immunoblotting or ELISA, respectively. In vivo study was performed on C57BI/ 6.ApoE2.ki mice. Heart, liver, spleen, thymus, pancreas, and kidneys were excised, fixed, and immunohistochemical studies were performed. Serial paraffin-embedded sections on proximal aorta sections were stained and the mean lesion area per animal was quantified. Human atherosclerotic vessel specimens from patients undergoing vascular surgery for atherosclerotic complications were fixed and immunohistochemical analysis was performed. Statistical significance was calculated with the Newman-Keuls test (given in detail in the online-only Data Supplement).

\section{Results \\ Trx-80 Reduces the Expression of M2 Markers in Murine Peritoneal Macrophages}

Macrophages rapidly bind Trx-80, which is later taken up by the cells and which can be detected primarily in the cytosol after extended periods of time. Interestingly, Trx-80 does not colocalize with acidic compartments such as lysosomes, and is barely degraded even after $24 \mathrm{~h}$ (Figs. IA and IB in the onlineonly Data Supplement).

We further analyzed whether human recombinant Trx-80 would reduce an $\mathrm{M} 2$ polarization of murine macrophages. Indeed, peritoneal macrophages from C57BL/6 mice were incubated with recombinant IL- 4 in the absence or in the presence of recombinant human Trx-80. As reported (Stein et al., 1992; Bouhlel et al., 2007), IL-4 induced significantly the M2 macrophage marker CD206 (also called mannose receptor); $3 . \mathrm{I} \pm 0.9$ a.u. versus control cells $\mathrm{I} .0 \pm 0.2 \mathrm{a}$.u., $P<0.00$ I (for mRNA; Fig. IA) and $3 \pm 0.2$ a.u. versus control

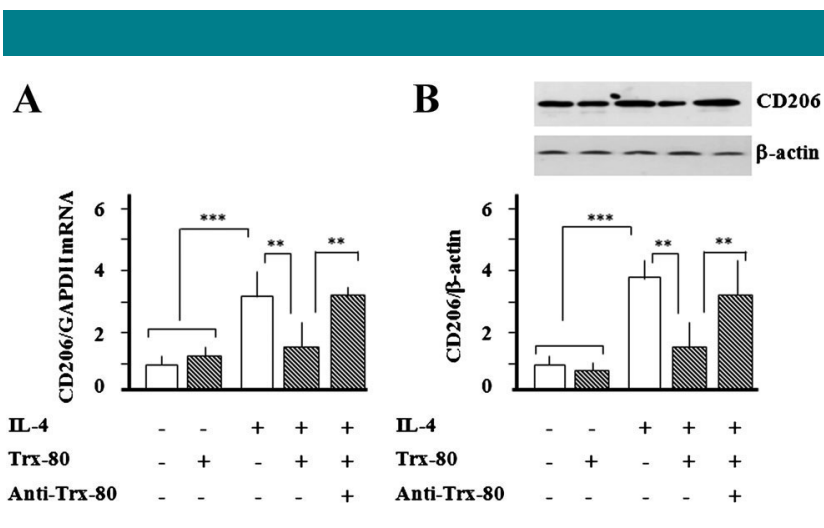

Fig. I. Trx-80 attenuates the $\mathbf{M} 2$ anti-inflammatory phenotype in freshly isolated murine peritoneal macrophages. A: Left part, shows mRNA levels of CD206 after treatment with recombinant Trx-80 ( I $\mu \mathrm{g} / \mathrm{ml})$, IL-4 (I $5 \mathrm{ng} / \mathrm{ml}$ ) and specific antibody against human Trx-80 $(5 \mu \mathrm{g} / \mathrm{ml})$ for $24 \mathrm{~h}$. mRNA levels of CD206 were quantified with qPCR and normalized to GAPDH. B: Right part, shows quantification of Western blots of CD206 and $\beta$-actin after treatment with recombinant Trx-80 (I $\mu \mathrm{g} / \mathrm{ml})$, IL-4 (I $5 \mathrm{ng} / \mathrm{ml})$, and specific antibody against human Trx-80 (5 $\mu \mathrm{g} / \mathrm{ml})$ for $24 \mathrm{~h}$. Data are presented as mean $\pm S E$ of three independent experiments performed in triplicate. ${ }^{* *} P<0.01$, ${ }^{* * *} P<0.001$, as indicated. One representative Western immunoblot was inserted. 
A

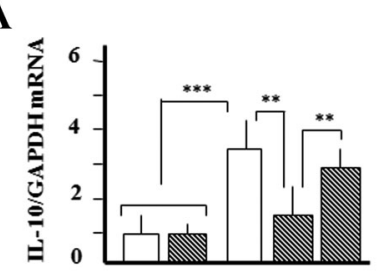

IL-4

Trx-80

Anti-Trx-80

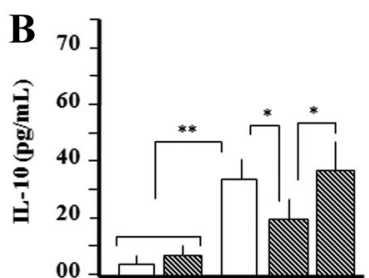

IL-4

Trx-80

Anti-Trx-80
00

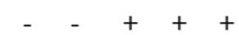

Fig. 2. Trx-80 attenuates the $M 2$ anti-inflammatory phenotype in freshly isolated murine peritoneal macrophages. A: Left part, shows mRNA levels of IL- I 0 after treatment with recombinant Trx-80 (I $\mu \mathrm{g} /$ $\mathrm{ml})$, IL-4 (I $5 \mathrm{ng} / \mathrm{ml})$, and specific antibody against human Trx-80 (5 $\mu \mathrm{g} /$ $\mathrm{ml}$ ) for $24 \mathrm{~h}$. mRNA levels of IL- 10 were quantified with qPCR and normalized to GAPDH. B, right part, shows the levels of IL-I 0 in cel supernatants after treatment with recombinant Trx-80 $(I \mu \mathrm{g} / \mathrm{ml})$, IL$4(15 \mathrm{ng} / \mathrm{ml})$ and specific antibody against human Trx-80 $(5 \mu \mathrm{g} / \mathrm{ml})$ for $24 \mathrm{~h}$. Data are presented as mean \pm SE of three independent experiments performed in triplicate. ${ }^{*} P<0.05,{ }^{* *} P<0.01,{ }^{* * *} P<0.01$, as indicated.

cells $I .0 \pm 0.2$ a.u., $P<0.00$ I (for protein; Fig. IB). In contrast, the expression of the marker CD206 marker was reduced by Trx-80. Thus, in IL-4-treated cells, Trx-80 significantly reduced the expression of CD206 mRNA from $3.1 \pm 0.9$ to

$\mathrm{I} .5 \pm 0.9$ a.u. $P<0.0 \mathrm{I}$ (Fig. IA) and CD206 protein level from $3.0 \pm 0.2$ to I. $5 \pm 0.9$ a.u. $(P<0.0$ I; Fig. IB $)$. The effect of TrX80 on macrophage polarization was specific, because it could be virtually abolished by an anti-Trx-80 antibody (Fig. IA,B). Of note, we used Trx-80 at I $\mu \mathrm{g} / \mathrm{ml}$ in all in vitro experiments reported in this manuscript, because in pilot concentrationresponse experiments, I $\mu \mathrm{g} / \mathrm{ml}$ Trx- 80 exerted the maximum effect on macrophage polarization in vitro (data not shown). Similarly, IL-4 induces the expression of IL- I0 ( $3.5 \pm 0.7$ a.u vs. control cells I $.0 \pm 0.4$ a.u., $P<0.00 \mathrm{I}$ (for mRNA; Fig. $2 \mathrm{~A}$ ) and $32 \pm 8 \mathrm{pg} / \mathrm{ml}$ versus control cells $4.5 \pm \mathrm{I} .4 \mathrm{pg} / \mathrm{ml}, P<0.0 \mathrm{l}$ (for protein; Fig. 2B) and concomitant administration of Trx-80 reduced such expression (from $3.5 \pm 0.7$ to $\mathrm{I} .4 \pm 0.2 \mathrm{a}$.u., $P<0.0 \mathrm{I}$ (for mRNA) and $32 \pm 8 \mathrm{pg} / \mathrm{ml}$ to $20 \pm 6 \mathrm{pg} / \mathrm{L}, P<0.05$ (for protein; Fig. 2A,B), respectively. Again, the effect of Trx-80 on macrophage polarization was specific, because the effect could be neutralized by an anti-Trx-80 antibody (Fig. 2A,B). A similar regulation of CD206 and IL- 10 expression by Trx-80 was observed in macrophages treated with IL-I 3 alone or in combination with IL-4 (not shown). In all experiments polymyxin $B$ was added in order to prevent any effect from a potential endotoxin contamination. Moreover, similar results were also observed in human monocyte-derived macrophages (Figs. II and III in the online-only Data Supplement).

\section{Trx-80 Induces the Expression of Murine MI Macrophages Markers}

To determine whether Trx- 80 affects the expression of the MI macrophage markers, peritoneal macrophages were treated with LPS in the absence or presence of recombinant human Trx-80. LPS significantly induced MI macrophage markers such as TNF- $\alpha, 5.2 \pm \mathrm{I} .0$ a.u. vs. control cells I. $0 \pm 0.2$ a.u., $P<0.00 \mathrm{I}$ (for mRNA; Fig. $3 \mathrm{~A}$ ) and $2.5 \pm 0.5 \mathrm{ng} / \mathrm{ml}$ versus control cells $0.5 \pm 0.2 \mathrm{ng} / \mathrm{ml}, P<0.0$ I (for protein; Fig. $3 \mathrm{~B}$ ). In addition, the expression of TNF- $\alpha$ was significantly induced by Trx- 80 at $\mathrm{l} \mu \mathrm{g} / \mathrm{ml}$ in LPS-treated cells. Thus, Trx-80 enhanced the LPS-

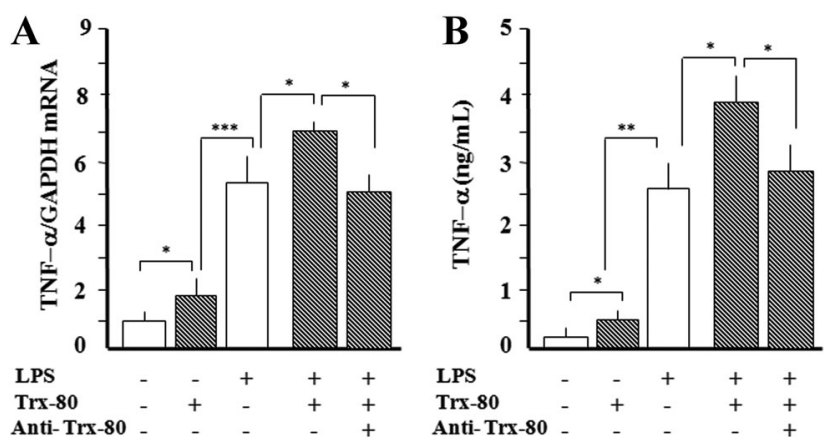

Fig. 3. Trx-80 promotes the MI pro-inflammatory phenotype in freshly isolated murine peritoneal macrophages. A: Left part, shows mRNA levels of TNF- $\alpha$ after treatment with recombinant Trx-80 ( I $\mu \mathrm{g} / \mathrm{ml})$, LPS ( $100 \mathrm{ng} / \mathrm{ml})$, and specific antibody against human Trx$80(5 \mu \mathrm{g} / \mathrm{ml})$ for $24 \mathrm{~h}$. mRNA levels of TNF- $\alpha$ were quantified with qPCR and normalized to GAPDH. B: Right part, shows the levels of TNF- $\alpha$ in cell supernatants after treatment with recombinant Trx-80 $(\mathrm{I} \mu \mathrm{g} / \mathrm{ml})$, LPS ( $100 \mathrm{ng} / \mathrm{ml})$, and specific antibody against human Trx$80(5 \mu \mathrm{g} / \mathrm{ml})$ for $24 \mathrm{~h}$. Data are presented as mean \pm SE of three independent experiments performed in triplicate. ${ }^{*} P<0.05$, ${ }_{* *} \boldsymbol{P}<0.01$, ${ }^{* * *} \boldsymbol{P}<0.001$, as indicated.

induced expression of TNF- $\alpha$ from $5.2 \pm 1.0$ to $6.8 \pm 0.2$ a.u.; $P<0.05$ (for mRNA) and from $2.5 \pm 0.5$ to $3.8 \pm 0.6 \mathrm{ng} / \mathrm{ml}$; $P<0.05$ (for protein; Fig. 3A,B, respectively). Moreover, the effect was also almost completely neutralized by an anti-Trx-80 antibody (Fig. 3A,B). Similarly, LPS significantly induces the expression of MCP-I (another MI marker). Thus, in the presence of LPS, the MCP-I mRNA increased from $1.0 \pm 0.2$ (control cells) to $7.8 \pm 0.6$ a.u. $P<0.00$ I (Fig. $4 \mathrm{~A}$ ) and for the

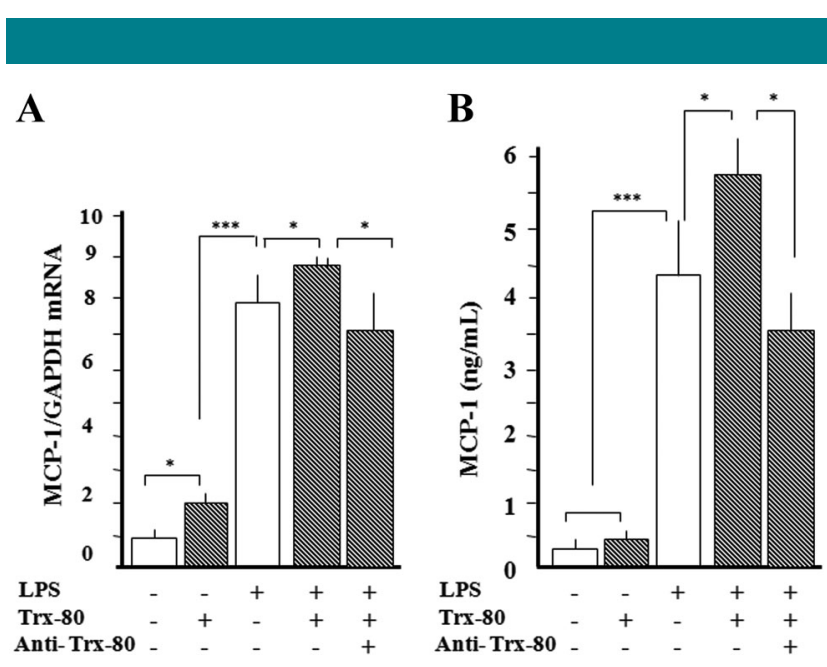

Fig. 4. Trx-80 promotes the MI pro-inflammatory phenotype in freshly isolated murine peritoneal macrophages. A: Left part, shows mRNA levels of MCP-I after treatment with recombinant Trx-80 ( $\mathrm{l} \mu \mathrm{g} / \mathrm{ml})$, LPS ( $100 \mathrm{ng} / \mathrm{ml})$, and specific antibody against human Trx$80(5 \mu \mathrm{g} / \mathrm{ml})$ for $24 \mathrm{~h}$. mRNA levels of MCP-I were quantified with qPCR and normalized to GAPDH. B: Right part, shows the levels of MCP-I in cell supernatants after treatment with recombinant Trx-80 $(\mathrm{I} \mu \mathrm{g} / \mathrm{ml})$, LPS $(100 \mathrm{ng} / \mathrm{ml})$ and specific antibody against human Trx$80(5 \mu \mathrm{g} / \mathrm{ml})$ for $24 \mathrm{~h}$. Data are presented as mean \pm SE of three independent experiments performed in triplicate. ${ }^{*} P<0.05$, $* * * P<0.001$, as indicated. 

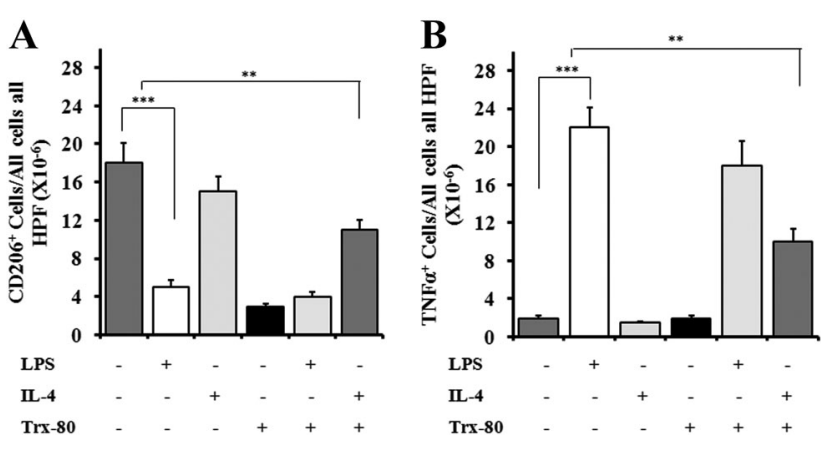

Fig. 5. Trx-80 attenuates $M 2$ polarization of murine thymusmacrophages. C57BI/6.ApoE2.Ki mice were intravenously injected with LPS (1 $0 \mu \mathrm{g} / 30 \mathrm{~g}$ body weight (b.w.)), IL-4 (500 ng/30 g b.w.) and or Trx-80 (30 $\mu \mathrm{g} / 30 \mathrm{~g}$ b.w.) at Days 0 and 3. At Day 5 , the mice were sacrificed. Paraffin embedded serial sections $(5 \mu \mathrm{m})$ of the thymus were immunohistochemically analyzed with antibodies either against the M2 marker CD206 (A) or MI marker TNF- $\alpha$ (B), and fluorescently labeled secondary $F\left(a^{\prime}\right)_{2}$; nuclei were stained with DAPI. TNF- $\alpha$ and CD206 positive cells were quantified using ImageJ software (NIH). The data represent the number of positive cells/HPF (magnification $200 \times)$, mean \pm SEM, $n=8$. ${ }^{* *} P<0.01$, ${ }^{* * *} P<0.001$ as indicated.

protein level from $0.5 \pm 0.2$ (control cells) to $4.8 \pm 1.2 \mathrm{ng} / \mathrm{ml}$; $P<0.05$ (Fig. 4B). In addition, the expression of MCP-I was further increased by Trx- 80 at I $\mu \mathrm{g} / \mathrm{ml}$ in LPS-treated cells. Thus, Trx-80 increases the LPS-induced expression of MCP-I from $7.8 \pm 0.6$ to $9.0 \pm 0.2$ a.u.; $P<0.05$ (for mRNA; Fig. 4A) and from $4.8 \pm 1.2$ to $6.2 \pm 0.9 \mathrm{ng} / \mathrm{ml} ; P<0.05$ (for protein; Fig. 4B). In analogy to the previous experiments, the stimulation effect of Trx-80 on LPS-induced expression of MCP-I marker was totally abolished in the presence of the specific anti-Trx-80 antibody (Fig. 4A,B). Similar to murine peritoneal macrophages, Trx-80 inhibited the expression of M2 macrophage markers and increased the expression of $\mathrm{MI}$ markers in human monocyte-derived macrophages (Figs. IV and V in the onlineonly Data Supplement).

\section{Short Term Effects of Trx-80 on MI/M2 Macrophages in Tissues of ApoE2.Ki Mice}

Macrophages are highly plastic cells that enter target tissues and gain the phenotypic and functional attributes of their tissue of residence (Mantovani et al., 2005). To address such phenotypic changes, we analyzed the effect of Trx- 80 administration on the expression of MI/M2 markers in murine tissues. For the in vivo study, we injected mice with recombinant human Trx-80 at $30 \mu \mathrm{g} / \mathrm{g}$ b.w. because in a pilot study, mice injected with various doses of Trx-80, showed the maximum effect at $30 \mu \mathrm{g} / \mathrm{g}$ b.w. There were no changes in the expression of MI and M2 macrophage markers in spleen, pancreas and kidneys (data not shown). However, in agreement with the data obtained in vitro with murine peritoneal and human macrophages, Trx-80 decreased the number of $\mathrm{CD} 206^{+} \mathrm{M} 2$ and given together with IL-4 increased the TNF- $\alpha^{+}$MI macrophages in the thymus (Fig. 5). Moreover, it antagonized the IL-4- induced expression of CD206 in thymus macrophages (Fig. 5).

Trx-80 exhibited comparable effects on hepatic macrophages, where it antagonized the IL-4-induced expression of CD206 and potentiated the LPS-induced expression of TNF- $\alpha$ (Fig. 6). Trx-80 also enhanced the LPSinduced decrease of CD206 (Fig. 6). Thus, Trx-80 promotes MI
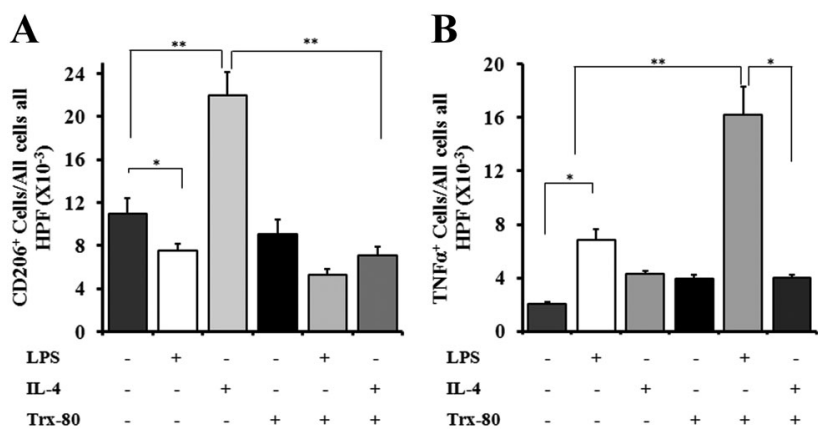

Fig. 6. Trx-80 attenuates $M 2$ polarization of murine livermacrophages. C57BI/6.ApoE2.Ki mice were intravenously injected with LPS (1 $0 \mu \mathrm{g} / 30 \mathrm{~g}$ body weight (b.w.)), IL-4 (500 ng/30 g b.w.) and/ or Trx-80 (30 $\mu \mathrm{g} / 30 \mathrm{~g}$ b.w.) at Days 0 and 3. At Day 5, the mice were sacrificed. Paraffin embedded serial sections (5 $\mu \mathrm{m})$ of liver macrophages were immunohistochemically analyzed with antibodies either against the M2 marker CD206 (A) or the MI marker TNF- $\alpha$ (B), and fluorescently labeled secondary $F\left(a b^{\prime}\right)_{2}$; nuclei were stained with DAPI. TNF- $\alpha$ and CD206 positive cells were quantified using ImageJ software (NIH). The data represent the number of positive cells/HPF (magnification $200 \times$ ), mean \pm SEM, $n=8$. ${ }^{*} P<0.05$, ${ }_{* *} P<0.01,{ }^{* * *} P<0.001$ as indicated.

macrophage markers and inhibits the $M 2$ phenotype in tissue macrophages.

\section{Trx-80 Colocalizes With MI Macrophages in Human Atherosclerotic Lesions}

Previous studies have shown the presence of MI (Ross, 1999) and M2 (Bouhlel et al., 2007) macrophages in atherosclerotic lesions. However, it was unknown whether Trx-80 would colocalize with $\mathrm{MI}$ or $\mathrm{M} 2$ markers in complicated atherosclerotic lesions. Not unexpected, the staining pattern of CD206 in serial sections of human atherosclerotic plaques confirmed that Trx-80-expressing cells colocalize with the $\mathrm{MI}$ macrophage marker TNF- $\alpha$. In contrast, Trx-80 does not colocalize with CD206, a marker of inflammatory M2 macrophages (Fig. 7), indicating that Trx-80 could promote the MI differentiation in human atherosclerotic vessels as well.

\section{Chronic Treatment With Trx-80 Increases the Number of Lesional MI Macrophages and Enhances the Size of Atherosclerotic Lesions}

ApoE2.Ki hyperlipoproteinemic mice challenged repeatedly with LPS exhibit a significant increase in lesion size compared to control animals, as we have previously shown (Cuaz-Perolin et al., 2008). Lesional macrophages in these mice express high levels of TNF- $\alpha$ and low levels of CD206 exhibiting predominantly the proinflammatory MI phenotype. When LPSinjected ApoE2.Ki mice were additionally treated with human recombinant Trx-80, the amount of TNF- $\alpha^{+}$MI macrophages was significantly potentiated, and the number of $\mathrm{CD}_{206}{ }^{+} \mathrm{M} 2$ macrophages was significantly reduced (Fig. 8A). Similarly, liver tissue of mice chronically treated with Trx-80 exhibited increased expression of $\mathrm{MI}$ macrophage marker TNF- $\alpha$, but reduced expression of the M2 marker CD206 (data not shown). Moreover, Trx-80 significantly increased the size of aortic atherosclerotic lesions in ApoE2.Ki

hyperlipoproteinemic mice challenged with LPS (100 $18 \%$ (LPS-challenged) vs. $136 \% \pm 21 \%$ (Trx-80-treated LPSchallenged mice; $\mathrm{n}=8$ ); $\mathrm{P}<0.0 \mathrm{I}$ (Fig. 8B)). 

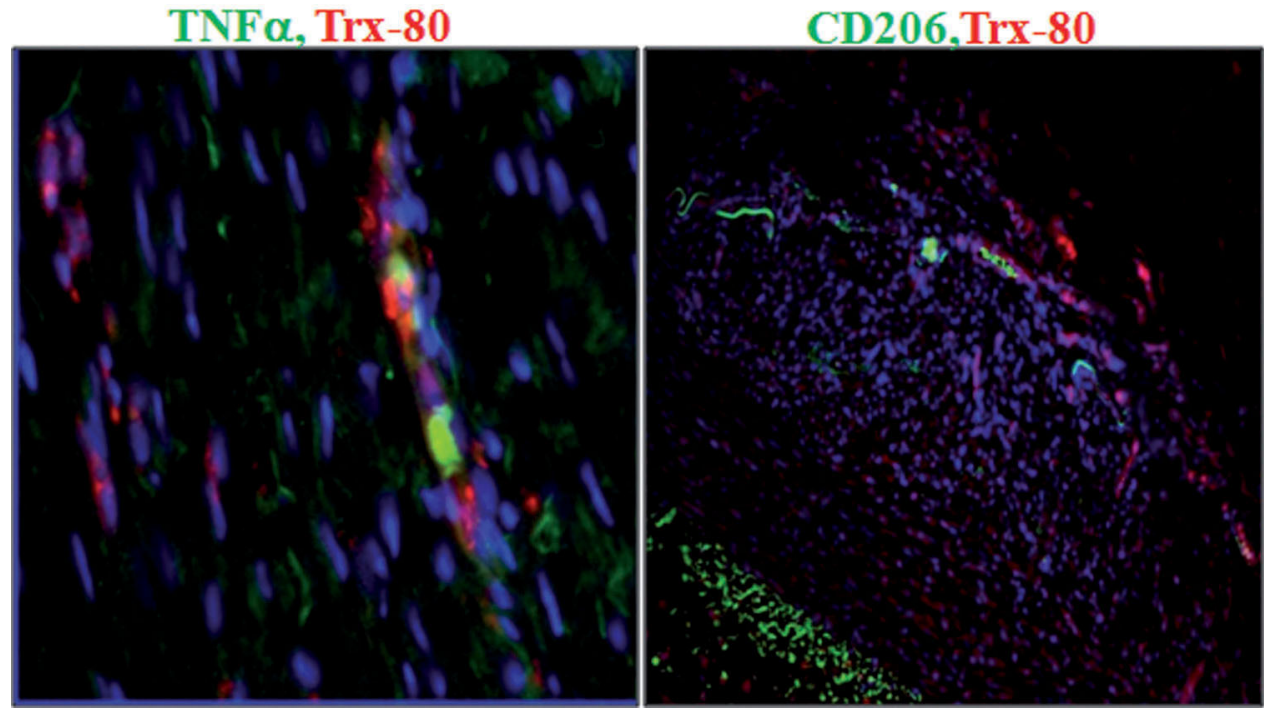

Fig. 7. Trx-80 colocalizes with MI, but not with $M 2$ macrophages in human atherosclerotic lesions. Serial sections of paraffin-embedded human atherosclerotic vessel specimens from five patients undergoing vascular surgery for atherosclerotic complications were double stained with Trx-80 and TNF- $\alpha$ or CD206 primary antibodies, respectively. TNF- $\alpha$ and CD206 were visualized by Cy2-conjugated secondary antibody (green). Trx-80monoclonal mouse antibody that reacts exclusively with the truncated protein was stained with Cy-5-conjugated secondary antibody (red). In control samples, the primary antibodies were substituted with control IgG. Sections were counterstained with hematoxylin. Original magnifications $400 \times$. Representative images are shown.

Treatment of macrophages With Trx-80 Enhances the ABCAI Expression in MI Macrophages But Does Not Affect the Reverse Cholesterol Transport

To determine the role of Trx-80 in lipid metabolism and its accumulation in the MI macrophages, the expression of

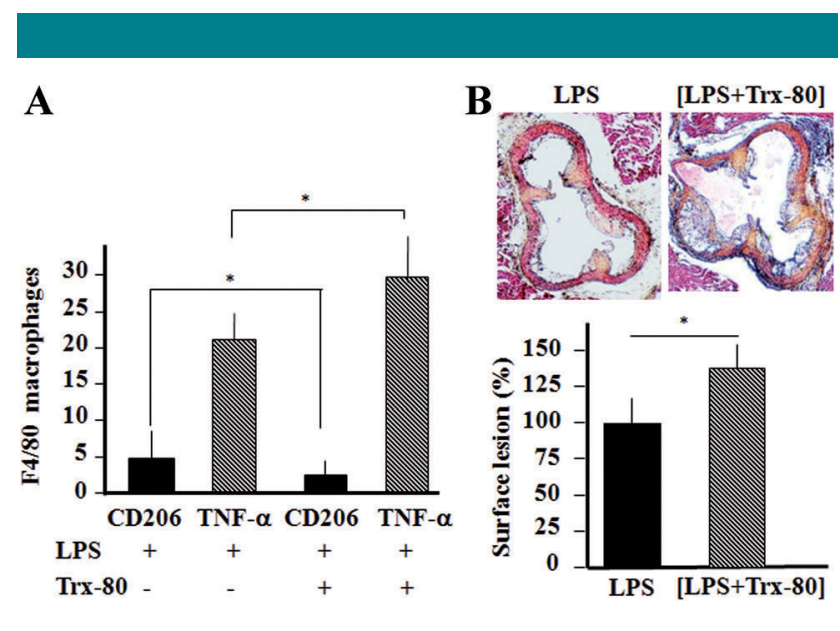

Fig. 8. Trx-80 induces $M I$ macrophage polarization in murine atherosclerotic lesions. C57BI/6.ApoE2.Ki mice were intravenously injected with LPS ( $10 \mu \mathrm{g} / 30 \mathrm{~g}$ b.w.) once weekly and daily with either Trx-80 (30 $\mu$ g/30 g b.w.) or PBS for 5 weeks, when the mice were sacrificed. Frozen serial sections $(7 \mu \mathrm{m})$ of proximal aortas were analyzed by immunohistochemistry using double immunostaining with antibodies either against the macrophage marker F4/80 and the MI marker TNF- $\alpha$ or the M2 marker CD206, respectively (A).

Furthermore, serial paraffin-embedded sections $(5 \mu \mathrm{m})$ of proxima aortas were prepared, stained with hematoxylin, eosin, and saffron for lesion area measurement. Three aortic sections, each separated by $100 \mu \mathrm{m}$, from eight mice were analyzed (B). Data are mean \pm SEM of eight mice, ${ }^{*} P<0.05$.
$A B C A I$, scavenger receptors SR-A, CD36, and LOX-I were studied. It was found that Trx-80 $(I \mu g / m l)$ significantly enhanced the expression of ABCAI in MI macrophages (LPStreated cells) compared to resting macrophages (RM; Fig. 9A), whereas the expression of SR-A, CD36 and LOX-I (data not shown) as well as the reverse cholesterol transport were not affected (Fig. 9B).

\section{Discussion}

Macrophages possess a remarkable diversity, which depends on the type, duration and concentration of environmental signals, including bacterial products and cytokines. Macrophage subpopulations exhibit differential gene expression, release different cytokines and secondary mediators, and express different cell surface antigens. According to their phenotype, macrophages are divided into two major populations, those which promote inflammation, and those which limit inflammation and support tissue remodeling and angiogenesis (Mantovani et al., 2009). In contrast to lymphocytes, which cannot be reprogrammed, macrophages retain plasticity, meaning that alteration of environmental signals could change the balance between $\mathrm{MI}$ and $M 2$ populations. Changing the composition of macrophage population in tissues would affect pathogenesis, evolution and complication of many diseases including atherosclerosis (Murray and Wynn, 20II). Therefore, identification of agents that might modulate the balance of macrophage polarization is of great importance.

In this manuscript we show that macrophages bind rapidly Trx-80, which is later taken up by the cells and which can be detected primarily in the cytosol after extended periods of time. Interestingly, Trx-80 does not colocalize with acidic compartments such as lysosomes, and is barely degraded even after $24 \mathrm{~h}$ (Figs. IA and IB in the online-only Data Supplement). Extracellular full length Trx-I also binds rapidly to the surface of macrophages, yet after $24 \mathrm{~h}, \mathrm{Trx}-\mathrm{I}$ is localized predominantly within the lysosomal compartment (El Hadri et al., 20I2). The 


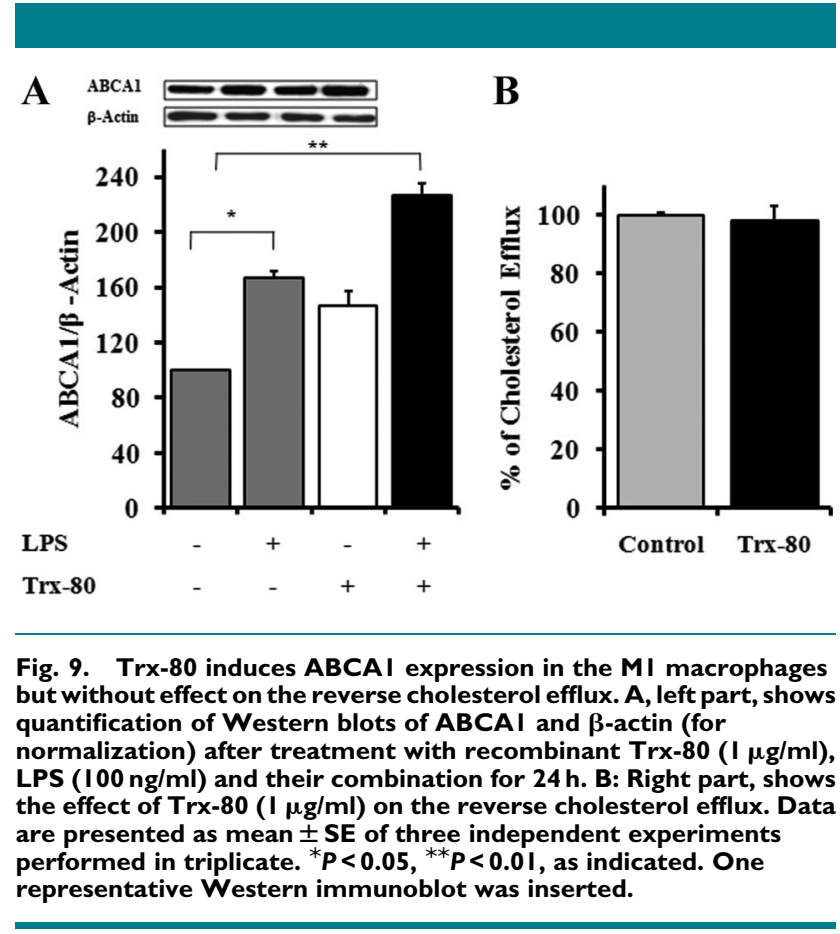

raison of such different localization is currently not known. Nevertheless, it is well documented that the lysosomal pathway of proteolysis is selective for cellular proteins containing a peptide sequence related to the Lys-Phe-Glu-Arg-GIn (KFERQ) motif. A heat shock protein of $73 \mathrm{kDa}$ binds to such peptide regions in proteins and mediates their transfer to lysosomes for degradation. Therefore, we hypothesized that the lysosomal localization of full length Trx-I but not of its truncated form, Trx-80, might be explained by a potential presence of the KFERQ motif in the C-terminal domain, which might be lost after cleavage of the protein. Unfortunately, we could not find such a KFERQ motif. Therefore, we considered another explanation. Thus, Cys-proteases such as cathepsin B are constitutively expressed in the lysosomes of human B cells (Rodriguez and Diment, 1995) and their activity requires active $\mathrm{SH}$ generating systems that protect them from oxidative inactivation. They play an important role in antigen processing, producing peptides, which can be recognized in the context of MHC class II (Matsunaga et al., I 993; Deussing et al., 1998). The enzymatic activity of cathepsin $B$ requires the presence of Trx. Accordingly, Trx is thought to represent a good $\mathrm{SH}$ donor candidate for the processing of disulfide-bonded multimeric antigens. Trx could therefore be considered as a molecular chaperonin involved in antigen processing (Kerblat et al., 1999), which could explain its presence within the lysosome. In contrast, Trx-80 lacks redox activity (Pekkari et al., 2000) and its presence within the lysosome might not be necessary. Another hypothesis could be considered as well. Thus, Trx-I is known to inhibit oxidative stress-induced apoptosis in different cell types (Andoh et al., 2002; Haendeler et al., 2002; Shioji et al., 2002). To overcome such apoptosis inhibition, cathepsin D (CatD), a lysosomal asparatic proteinase, induces degradation of Trx-I (Haendeler et al., 2005). Hence, the lysosomal localization of Trx-I might represent a mechanism used by macrophages to control the induction of apoptosis.

In addition, we show in the present study, that human Trx-80 potentiates the expression of pro-inflammatory $\mathrm{MI}$ macrophages through AP-I and Ref-I transcription factorindependent pathways (not shown), as evidenced by the increase of the markers TNF- $\alpha$ and MCP-I, characteristic of the MI polarization. In parallel, Trx-80 blunts the expression of anti-inflammatory M2 markers such as CD206 and IL- I0 through unknown mechanism. The correlation between the human macrophage subpopulations and their murine counterparts, particularly in atheroma, are still unknown. Therefore, it is important that we found similar effects in human as well as in murine macrophages. In addition, we complemented our in vitro experiments with in vivo studies using a hyperlipoproteinemic mouse model.

Our in vitro data showing promotion of $\mathrm{Ml}$ over $\mathrm{M} 2$ phenotype by Trx- 80 are supported by the in vivo data. In ApoE2.Ki mice treated intravenously with human recombinant Trx-80 for $2-5$ days or for 5 weeks, Trx- 80 increases expression of MI pro-inflammatory macrophage marker in thymus and in liver, as well as in the atherosclerotic lesions. In contrast, the high expression of macrophage MI markers observed in mice injected with LPS is significantly potentiated by the Trx-80 treatment. As a consequence, lesion surface area is significantly increased in mice treated with Trx-80 compared to mice treated with LPS alone. In addition, in human atherosclerotic plaques, we observed colocalization of Trx-80 with TNF- $\alpha$, a marker of proinflammatory MI macrophages, but not with CD206, a marker of anti-inflammatory M2 macrophages. This may be due to the Trx-80-induced activation of pro-inflammatory and pro-survival PI3K/Akt and MAP/ERK signaling pathways, a hypothesis that is currently under further investigations.

Taken together, these studies indicate that Trx- 80 functions as regulator of macrophage phenotype tipping the balance towards the pro-inflammatory MI state. As a consequence, atherosclerotic plaques become larger and probably more unstable.

Of note, in a previous publication, $\operatorname{Trx}-80$ was shown to induce differentiation of human $\mathrm{CDI} 4^{+}$monocyte into a new cell type designate as Trx-activated monocytes (TAMs) (Bizzarri et al., 2005). TAMs resemble immature dendritic cells (iDCs) generated in the presence of granulocyte-macrophage colony-stimulating factor (GM-CSF) and IL-4 (Bizzarri et al., 2005). Functional assays revealed that TAMs release significantly higher amounts of the pro-inflammatory cytokines such as TNF- $\alpha, I L-I \beta$, and IL- 6 and of the anti-inflammatory cytokine IL- I0 (Bizzarri et al., 2005). In our present study, we also show that Trx-80, either alone or in combination with LPS, increases the TNF- $\alpha$ and MCP-I expression and secretion by murine peritoneal macrophages as well as by HMDM. However, Trx-80 alone did not affect the expression of CD206 or IL- 10 in these cells. In contrast, in IL-4-treated macrophages, Trx-80 decreased CD206 and IL- 10 expression. The discrepancy with the data reported by Pekkari et al. (Bizzarri et al., 2005) who show an increase of IL- 10 with Trx-80 might be due to the cell type and/or the cell purification procedure and culture condition.

Furthermore, it has been shown recently that the expression of the cyclin-dependent kinase inhibitor pl $6^{\text {INK4a }}$ modulates the macrophage phenotype (Cudejko et al., 20I I; El Hadri et al., 2012). Thus, $\mathrm{pl}^{-1-}$ bone marrow-derived macrophages display a decreased response to classical polarizing by IFN $\gamma$ and LPS but an increased sensitivity to alternative polarization by IL-4 (Cudejko et al., 20I I). Therefore, one could assume that Trx-80 might reduce macrophage polarization into the $M 2$ phenotype through upregulation of p $16^{1 \mathrm{NK} 4 a}$. However, such a mechanism does not seem to be relevant because we did not observe any effect of Trx-80 on pl $6^{\mathrm{INK} 4}$ expression in macrophages (data not shown).

Of note, plasma cholesterol and triglycerides levels in LPStreated mice versus LPS and Trx-80-treated mice were not significantly different (Table II in the online-only Data Supplement). However, whether the progression and 
unstability of atheroma plaques attributed to $\mathrm{MI}$ phenotype could be explained by a difference in lipid metabolism and lipid accumulation in $\mathrm{MI}$ in comparison to $\mathrm{M} 2$ macrophages was unknown. Therefore, we conducted additional experiments on cultured macrophages to determine the level of ATP-binding cassette $A I$ (ABCAI) expression in the $M I, M 2$, and in RM as well as the influence of Trx- 80 on the $A B C A I$ gene expression. The results showed an increase of $A B C A I$ expression in $\mathrm{MI}$ macrophages in comparison to $M 2$ and RM and that Trx- 80 enhanced such expression suggesting that $\mathrm{MI}$ macrophages may have a high reverse cholesterol efflux activity which can be potentiated by Trx-80 (Fig. 9A).

In addition, the expression of the scavenger receptors SR-A, CD36, and LOX-I were similar in RM, M2, and MI macrophages and Trx-80 did not influence the expression of any of these genes (data not shown). Moreover, Trx- 80 does not affect the reverse cholesterol transport (Fig. 9B). The reason for this apparent contradiction is currently not known. One might speculate that Trx- 80 could activate macrophage pinocytosis through protein kinase $C$, which increases cholesterol accumulation. This cholesterol influx is counterbalanced by the increase of $A B C A I$ expression. Nevertheless, further studies are needed to clarify this point.

To date, the biological roles of Trx- 80 are still largely unknown. Previously, Trx-80 was termed eosinophil cytotoxicity-enhancing factor (ECEF) due to its eosinophil cytotoxicity and it has been first detected in the plasma of patients suffering from severe schistosomiasis (Dessein et al., 1984; Lenzi et al., 1985; Silberstein et al., 1989). Of note, these patients also developed atherosclerosis. It may be rewarding to identify other pathologies associated with Trx-80 generation and to study in greater detail the molecular mechanisms leading to its generation.

\section{Acknowledgments}

This work was supported by The Fondation de France, the Comité Mixte de Cooperation Universitaire (CMCU) exchange program between Tunisia and France, and the German Research Foundation, DFG.

\section{Literature Cited}

Andoh T, Chock PB, Chiueh CC. 2002. The roles of thioredoxin in protection against oxidative stress-induced apoptosis in SH-SY5Y cells. J Biol Chem 277:9655-9660.

Bertini R, Howard OM, Dong HF, Oppenheim J], Bizzarri C, Sergi R, Caselli G, Pagliei S, Romines B, Wilshire JA, Mengozzi M, Nakamura H, Yodoi J, Pekkari K, Gurunath R, Holmgren A, Herzenberg LA, Herzenberg LA, Ghezzi P. 1999. Thioredoxin, a redox enzyme released in infection and inflammation, is a unique chemoattractant for neutrophils, monocytes, and T cells. J Exp Med 189:1783-1789.

Billiet L, Furman C, Larigauderie G, Copin C, Brand K, Fruchart JC, Rouis M. 2005 Extracellular human thioredoxin-I inhibits lipopolysaccharide-induced interleukin-I beta expression in human monocyte-derived macrophages. J Biol Chem 280:40310-40318.

Bizzarri C, Holmgren A, Pekkari K, Chang G, Colotta F, Ghezzi P, Bertini R. 2005.

Requirements for the different cysteines in the chemotactic and desensitizing activity of human thioredoxin. Antioxid Redox Signal 7:1 189-1194.

Bouhlel MA, Derudas B, Rigamonti E, Dievart R, Brozek J, Haulon S, Zawadzki C, Jude B, Torpier G, Marx N, Staels B, Chinetti-Gbaguidi G. 2007. PPARgamma activation primes human monocytes into alternative M2 macrophages with anti-inflammatory properties. Cell Metab 6:137-143.

Cortes-Bratti X, Basseres E, Herrera-Rodriguez F, Botero-Kleiven S, Coppotelli G, Andersen JB, Masucci MG, Holmgren A, Chaves-Olarte E, Frisan T, Avila-Carino J. 20II. Thioredoxin 80 -activated-monocytes (TAMs) inhibit the replication of intracellular pathogens. PLoS ONE 6:el6960.

Cuaz-Perolin C, Billiet L, Bauge E, Copin C, Scott-Algara D, Genze F, Buchele B, Syrovets T, Simmet T, Rouis M. 2008. Antiinflammatory and antiatherogenic effects of the NF-kappaB inhibitor acetyl-I I-keto-beta-boswellic acid in LPS-challenged ApoE-I- mice.

Arterioscler Thromb Vasc Biol 28:272-277.
Cudejko C, Wouters K, Fuentes L, Hannou SA, Paquet C, Bantubungi K, Bouchaert E, Vanhoutte J, Fleury S, Remy P, Tailleux A, Chinetti-Gbaguidi G, Dombrowicz D, Staels B, Paumelle R. 20II. pI6INK4a deficiency promotes IL-4-induced polarization and inhibits proinflammatory signaling in macrophages. Blood II 8:2556-2566.

Dessein AJ, Lenzi HL, Bina JC, Carvalho EM, Weiser WY, Andrade ZA, David JR. 1984 Modulation of eosinophil cytotoxicity by blood mononuclear cells from healthy subjects and patients with chronic schistosomiasis mansoni. Cell Immunol 85:100-113.

Deussing J, Roth W, Saftig P, Peters C, Ploegh HL, Villadangos JA. 1998. Cathepsins B and D are dispensable for major histocompatibility complex class II-mediated antigen presentation. Proc Natl Acad Sci USA 95:4516-4521.

Di Trapani G, Perkins A, Clarke F. 1998. Production and secretion of thioredoxin from transformed human trophoblast cells. Mol Hum Reprod 4:369-375.

El Hadri K, Mahmood DF, Couchie D, Jguirim-Souissi I, Genze F, Diderot V, Syrovets T, Lunov $\mathrm{O}$, Simmet T, Rouis M. 20I2. Thioredoxin-I promotes anti-inflammatory macrophages of the M2 phenotype and antagonizes atherosclerosis. Arterioscler Thromb Vasc Biol 32:1445-1452

Forstermann U. 2008. Oxidative stress in vascular disease: Causes, defense mechanisms and potential therapies. Nat Clin Pract Cardiovasc Med 5:338-349.

Gordon S. 2003. Alternative activation of macrophages. Nat Rev Immunol 3:23-35.

Gordon S. 2007. The macrophage: Past, present and future. Eur J Immunol 37:S9-SI7.

Haendeler J, Hoffmann J, Tischler V, Berk BC, Zeiher AM, Dimmeler S. 2002. Redox regulatory and anti-apoptotic functions of thioredoxin depend on S-nitrosylation at cysteine 69. Nat Cell Biol 4:743-749.

Haendeler J, Popp R, Goy C, Tischler V, Zeiher AM, Dimmeler S. 2005. Cathepsin D and $\mathrm{H}_{2} \mathrm{O}_{2}$ stimulate degradation of thioredoxin-I: Implication for endothelial cell apoptosis. J Biol Chem 280:42945-4295I.

Kerblat I, Drouet C, Chesne S, Marche PN. 1999. Importance of thioredoxin in the proteolysis of an immunoglobulin $\mathrm{G}$ as antigen by lysosomal Cys-proteases. Immunology 97:62-68.

Lemarechal H, Anract P, Beaudeux JL, Bonnefont-Rousselot D, Ekindjian OG, Borderie D. 2007. Impairment of thioredoxin reductase activity by oxidative stress in human rheumatoid synoviocytes. Free Radic Res 41:688-698.

Lenzi HL, Mednis AD, Dessein AJ. 1985. Activation of human eosinophils by monokines and lymphokines: Source and biochemical characteristics of the eosinophil cytotoxicityenhancing activity produced by blood mononuclear cells. Cell Immunol 94:333-346.

Lovren F, Pan Y, Quan A, Szmitko PE, Singh KK, Shukla PC, Gupta M, Chan L, Al-Omran M, Teoh H, Verma S. 2010. Adiponectin primes human monocytes into alternative antiinflammatory M2 macrophages. Am J Physiol Heart Circ Physiol 299:H656-H663.

Lumeng CN, Bodzin JL, Saltiel AR. 2007. Obesity induces a phenotypic switch in adipose tissue macrophage polarization. I Clin Invest | 17: 175-184.

Mantovani A, Muzio M, Garlanda C, Sozzani S, Allavena P. 200I. Macrophage control of inflammation: Negative pathways of regulation of inflammatory cytokines. Novartis Found Symp 234:120-131; discussion 131-125.

Mantovani A, Sica A, Locati M. 2005. Macrophage polarization comes of age. Immunity 23:344-346.

Mantovani A, Garlanda C, Locati M. 2009. Macrophage diversity and polarization in atherosclerosis: A question of balance. Arterioscler Thromb Vasc Biol 29:1419-1423.

Matsunaga Y, Saibara T, Kido H, Katunuma N. 1993. Participation of cathepsin B in processing of antigen presentation to MHC class II. FEBS Lett 324:325-330.

Murray PJ, Wynn TA. 20II. Obstacles and opportunities for understanding macrophage polarization. J Leukoc Biol 89:557-563.

Odegaard JI, Chawla A. 2008. Mechanisms of macrophage activation in obesity-induced insulin resistance. Nat Clin Pract Endocrinol Metab 4:619-626.

Ohashi K, Parker JL, Ouchi N, Higuchi A, Vita JA, Gokce N, Pedersen AA, Kalthoff C, Tullin S, Sams A, Summer R, Walsh K. 2010. Adiponectin promotes macrophage polarization toward an anti-inflammatory phenotype. J Biol Chem 285:6153-6160.

Ostos MA, Recalde D, Zakin MM, Scott-Algara D. 2002. Implication of natural killer T cells in atherosclerosis development during a LPS-induced chronic inflammation. FEBS Lett 519:23-29.

Pekkari K, Holmgren A. 2004. Truncated thioredoxin: Physiological functions and mechanism. Antioxid Redox Signal 6:53-61.

Pekkari K, Gurunath R, Arner ES, Holmgren A. 2000. Truncated thioredoxin is a mitogenic cytokine for resting human peripheral blood mononuclear cells and is present in human plasma. I Biol Chem 275:37474-37480.

Pekkari K, Avila-Carino J, Bengtsson A, Gurunath R, Scheynius A, Holmgren A. 200 I Truncated thioredoxin (Trx80) induces production of interleukin- 12 and enhances CDI4 expression in human monocytes. Blood 97:3184-3190

Rodriguez GM, Diment S. 1995. Destructive proteolysis by cysteine proteases in antigen presentation of ovalbumin. Eur J Immunol 25:1823-1827.

Ross R. 1999. Atherosclerosis-An inflammatory disease. N Engl J Med 340:1 I5-126.

Savill J, Dransfield I, Gregory C, Haslett C. 2002. A blast from the past: Clearance of apoptotic cells regulates immune responses. Nat Rev Immunol 2:965-975.

Shioji K, Kishimoto C, Nakamura H, Masutani H, Yuan Z, Oka S, Yodoi J. 2002 Overexpression of thioredoxin- $I$ in transgenic mice attenuates adriamycin-induced cardiotoxicity. Circulation 106:1403-1409.

Silberstein DS, Ali MH, Baker SL, David JR. 1989. Human eosinophil cytotoxicity-enhancing factor. Purification, physical characteristics, and partial amino acid sequence of an active polypeptide. J Immunol I43:979-983.

Stein M, Keshav S, Harris N, Gordon S. 1992. Interleukin 4 potently enhances murine macrophage mannose receptor activity: A marker of alternative immunologic macrophage activation. J Exp Med 176:287-292

Sullivan PM, Mezdour H, Quarfordt SH, Maeda N. 1998. Type III hyperlipoproteinemia and spontaneous atherosclerosis in mice resulting from gene replacement of mouse Apoe with human Apoe*2. J Clin Invest 102:130-135.

Yamawaki H, Haendeler J, Berk BC. 2003. Thioredoxin: A key regulator of cardiovascular homeostasis. Circ Res 93:1029-1033. 